\title{
Correction to: Welfare chauvinism in times of labour market segmentation: how different employment contracts moderate the impact of welfare chauvinism on support for radical right parties
}

\section{Zhen Jie $\mathrm{Im}^{1}$}

Published online: 7 March 2022

(c) The Author(s) 2022

\section{Correction to: Comparative European Politics (2021) 19:94-116 https://doi.org/10.1057/s41295-020-00224-3}

The article Welfare chauvinism in times of labour market segmentation: how different employment contracts moderate the impact of welfare chauvinism on support for radical right parties written by Zhen Jie Im was originally published electronically on the publisher's internet portal on [12 November 2020] without open access. With the author(s)' decision to opt for Open Choice, the copyright of the article changed on [16 Feb 2022] to (C) The Author(s) 2022 and the article is forthwith distributed under a Creative Commons Attribution Open Access funding enabled and organized by ReNEW and Copenhagen Business School.

\begin{abstract}
Open Access This article is licensed under a Creative Commons Attribution 4.0 International License, which permits use, sharing, adaptation, distribution and reproduction in any medium or format, as long as you give appropriate credit to the original author(s) and the source, provide a link to the Creative Commons licence, and indicate if changes were made. The images or other third party material in this article are included in the article's Creative Commons licence, unless indicated otherwise in a credit line to the material. If material is not included in the article's Creative Commons licence and your intended use is not permitted by statutory regulation or exceeds the permitted use, you will need to obtain permission directly from the copyright holder. To view a copy of this licence, visit http://creativecommons.org/ licenses/by/4.0/.
\end{abstract}

Publisher's Note Springer Nature remains neutral with regard to jurisdictional claims in published maps and institutional affiliations.

The original article can be found online at https://doi.org/10.1057/s41295-020-00224-3.

Zhen Jie Im

zhen.im@helsinki.f

1 Department of Social Research, University of Helsinki, Unioninkatu 35, 00014 Helsinki, Finland 